\title{
Erythroderma: analysis of 247 cases
}

\author{
Cidia Vasconcellos, Paula P. Domingues, Valéria Aoki, Ricardo K. Miyake, \\ Naim Sauaia, José Eduardo C. Martins
}

\author{
School of Medicine, University of S. Paulo - Brazil (C.V., N.S., J.E.C.M.) \\ Hospital of Clinics, School of Medicine, University of S. Paulo-Brazil (P.P.D., V.A., R.K.M.)
}

\begin{abstract}
The profile of 247 patients with erythroderma during a 23 year period from January, 1962 through March, 1985, with a follow-up period ranging from 1 to 26 years were analysed. The patients presented with diffuse erythema, scaling and pruritus of more than 2 months' duration, and the age ranged from 16 to 60 years. Psoriasis was the most frequent underlying disease with an estimated frequency of $44.9 \%$, the reaction to the use of drugs appeared in $7.3 \%$ of total cases and association with retlculosis showed a frequency of $4.1 \%$. The cause of the erythroderma could not be determined in $29.2 \%$ of the cases. Sex differences in terms of underlying diseases were not observed. One or more skin biopsies along with the clinical findings were diagnostic or suggestive of the underlying disease in $63.6 \%$ of the cases. Repeated skin biopsies are recommended as the best method for etiologic diagnosis of erythroderma. At $P=0.05$ significance level, mascullne/feminine ratio of $2: 1$ was found. The question arises wether causal agent of erythroderma may not be somehow related to different exposure by sex to environmental antigens.
\end{abstract}

Dermatitis, exfoliative; epidemiology incidence.

\section{Introduction}

Erythroderma is a syndrome characterized by diffuse erythema, scaling, pruritus and prolonged course. Systemic manifestations may be present and prognosis is cause-dependent (Abrahams et $\mathrm{al}^{1}$; Adam $^{2}$; Fitzpatrick et $\mathrm{al}^{4}$; Gatti et al ${ }^{6}$; Helm ${ }^{10}$; Nebenzahl et a ${ }^{13}$; Nicolis \& Helwig ${ }^{14}$; Nigam et al ${ }^{15}$; Rook et $\mathrm{al}^{17}$ and Sampaio et $\mathrm{al}^{18}$ ).

In 1868, Hebra (apud Abrahams et al $^{1}$ and Nebenzahl et $\mathrm{al}^{13}$ ) proposed a classification based on clinical features: Hebra's pityriasis rubra, Brock's exfoliative dermatitis, scarlatiniform erythema and epidermal exfoliative dermatitis.

In 1913, Nicolis and Helwig ${ }^{14}$, after studying 135 patients with erythroderma, proposed a classification based on etiology: a) use of drug related $40 \%$; b) previous dermatosis related $-26.8 \%$; c) mycosis fungoides and lymphoma related $-17.8 \%$; d) internal malignancy $-2.8 \%$; e) miscellaneous etiology $-0.7 \%$; and f) unknown etiology $-11.9 \%$.

Montgomery ${ }^{2}$ established another classification based on histopathologic findings: a) idio- pathic or primary; and b) secondary to an underlying dermatosis or reticulosis.

According to Rabello et al. ${ }^{16}$, the patients with erythroderma do not show any significant alteration of routine laboratory tests. Montgomery ${ }^{12}$ stressed usefulness of multiple skin biopsies as a diagnostic and follow-up method.

Treatment must be directed towards the underlying diseases, although general measures should not be forgotten (Nebenzahl et al ${ }^{13}$.

The objective of the present work is to profile the etiology of erythroderma and to verify if there was a predominance of the syndrome according to sex.

\section{Subjects and methods}

Two hundred and forty seven patients with erythroderma seen at Dermatology Unit of a Hospital of Clinics located at the city of S. Paulo, Brazil, from 1962 through 1985, were studied. Diffuse erythema and scaling accompanied by pruritus

Reprints: Cidia Vasconcellos - School of Medicine, University of S. Paulo - Av, Dr, Amaldo, 455 - Sola 29 - 01246-903 - S. Paulo, SP - Brazil - Fax: (011) 881-7799.

The publication of this article was supported by FAPESP (Process 95/2290-6).

Received in 5.23.1994. Approved in 3.16.1995. 
lasting over two months in duration were used as diagnostic criteria. The patient's age and place of origin registered at the first visit were used for stastistical analysis.

The patients were grouped according to the clinical diagnosis as seen:

a) Related to previous dermatosis: psoriasis, eczema, atopic eczema, seborrheic eczema, lamellar ichthyosis, erythrokeratoderma (systemic and progressive forms), pityriasis rubra pilaris and Darier's disease;

b) Drug use related: contact eczema, systemic eruption by drug use and photosensitivity;

c) Reticulosis and leukemia related: lymphoma, mycosis fungoides and Sézary's syndrome;

d) Miscellaneous: nodular scabies;

f) Unknown etiology: the patients who did not have a known cause at the last visit.

Light microscopy study of skin biopsies was done and showed one of the following patterns:

a) Subacute or chronic dermatitis;

b) Subacute or chronic psoriasiform dermatitis;

c) Psoriasis;

d) Vasculitis;

e) Suggestive of lymphoma;

f) Others: lamellar ichthyosis, epidermolytic hyperkeratosis and Darier's disease, and

g) Dermatopathic lymphadenitis.

The study has been designed as a case study* (Forattinis ${ }^{5}$ and Leser et al). ${ }^{1 "}$ The subject group was compared to patients with dermatosis withouterythrodenna from the same hospital during the same time period.

The Special Program for Social Science (SPSS) was used for the analysis of the data.

In order to compare the ratio between three or more categories in the contingency tables, Goodman's $s^{g}$ or Kolmogorov-Sminnoff's (apud Costa-Neto) ${ }^{3}$ tests, along with Pearson's chisquare statistics (Costa-Neto) ${ }^{3}$ were applied, respecting the frequency restrictions.

As for the tendency evaluation, adjustment by the method of minimum square and the regression line was adopted, and the angular coefficient test was applied, according to Student's t distribution, with the necessary adjustments. The comparison

* Personal communication of Bruce B. Duncan, D. Rumel, M.I. Schimidt, 1988. between two angular coefficients, with the same adjustment, was possible due to Student's $t$ distribution (Costa-Neto) ${ }^{3}$. The significance level adopted was $\mathrm{P}=0.05$.

\section{Results}

Table 1 shows a greater number of feminine patients in the group without erythroderma $\left(t_{\text {calc }}=5.051\right.$; c.p. (cut point $)=2.131$ ), and a greater number of masculine patients in the group with erythroderma $\left(t_{\mathrm{calc}}=0.295 ; \mathrm{c} . \mathrm{p} .=2.074\right)$, however, this difference has no statistical significance $\left(D_{\max }=0.140 ; c . p,=0.163\right)$.

Table $\uparrow$ - Distribution of patients according to sex and disease (Jan/62-Mar/85).

\begin{tabular}{|c|c|c|c|c|}
\hline \multirow[t]{2}{*}{ Sex } & \multicolumn{2}{|c|}{$\begin{array}{c}\text { Patients with } \\
\text { erythroderma } \\
\text { (Jan/62-Mar/85) }\end{array}$} & \multicolumn{2}{|c|}{$\begin{array}{l}\text { Patients without } \\
\text { erythroderma } \\
\text { (Jan/62-Dec/78) }\end{array}$} \\
\hline & n & $\%$ & $n$ & $\%$ \\
\hline $\begin{array}{l}\text { Masculine } \\
\text { Feminine }\end{array}$ & $\begin{array}{r}162- \\
85-\end{array}$ & $\begin{array}{l}65.6 \\
34.4\end{array}$ & $\begin{array}{l}25,750- \\
32,256-\end{array}$ & $\begin{array}{l}44.4 \\
55.6\end{array}$ \\
\hline Total & \multicolumn{2}{|c|}{$247-100.0$} & \multicolumn{2}{|c|}{$58,006 \cdot 100.0$} \\
\hline
\end{tabular}

Although, when patients were sub-divided into sub-groups of 5 year periods (Table 2), according to the time of the first visit, a significantly higher number of masculine patients with erythroderma was found (Table 2; 1st. 5 year-period: $\lambda_{\text {calc }}^{2}=5.156$; 2 nd. 5 year-period: $\lambda_{\text {calc }}^{2}=15.751$; 3rd. 5 year-period $\lambda_{\text {calc }}^{2}=10.309$; c.p. $=3.841$ ).

Table 3 shows no differences by sex among patients without erythroderma who sought assistance in the outpatient clinic.

Table 2 - Dlstribution of patlents in sub-groups of 5-year periods (Jan/62-Mar/85).

\begin{tabular}{lccccc}
\hline & \multicolumn{2}{c}{ Patients with erythrod } & & \multicolumn{2}{c}{ Patients without erythrod } \\
\cline { 2 - 3 } \cline { 5 - 6 } Year & $\begin{array}{c}\text { Masculine } \\
n(\%)\end{array}$ & $\begin{array}{c}n(\%) \\
n(\%)\end{array}$ & & $\begin{array}{c}\text { Masculine } \\
n(\%)\end{array}$ & $\begin{array}{c}\text { Feminine } \\
n(\%)\end{array}$ \\
\hline $1962-1966$ & $10(0.1)$ & $2(0.0)$ & $7,335(99.9)$ & $8,449(99.9)$ \\
$1967-1971$ & $24(0.3)$ & $5(0.1)$ & & $6,876(99.6)$ & $8,619(99.9)$ \\
$1972-1976$ & $28(0.3)$ & $12(0.1)$ & $8,313(99.7)$ & $10,777(99.9)$ \\
$1977-1981$ & 55 & 36 & $*$ & $*$ \\
$1982-1985 \#$ & 45 & 30 & $*$ & $*$ \\
\hline Total & 162 & 85 & 22,524 & 27,845 \\
\hline
\end{tabular}

\# 4 year interval

- not reported 
Table 3 - Distribution of new cases according to sex, age and year of first vislt (Jan/62-Dec/78).

\begin{tabular}{|c|c|c|c|c|c|c|c|c|}
\hline \multirow{2}{*}{$\begin{array}{l}\text { Age (years) } \\
\text { Year \ Sex }\end{array}$} & \multicolumn{2}{|c|}{$0-15$} & \multicolumn{2}{|c|}{$16-60$} & \multicolumn{2}{|c|}{$61+$} & \multicolumn{2}{|c|}{ Total } \\
\hline & $\mathbf{M}$ & $\mathbf{F}$ & $\mathbf{M}$ & $F$ & $\mathbf{M}$ & $F$ & $M$ & $\mathrm{~F}$ \\
\hline $\begin{array}{l}1962 \\
1963 \\
1964 \\
1965 \\
1966 \\
1967 \\
1968 \\
1969 \\
1970 \\
1971 \\
1972 \\
1973 \\
1974 \\
1975 \\
1976 \\
1977 \\
1978\end{array}$ & $\begin{array}{l}328 \\
498 \\
491 \\
663 \\
487 \\
448 \\
433 \\
378 \\
442 \\
429 \\
579 \\
598 \\
437 \\
488 \\
425 \\
375 \\
519\end{array}$ & $\begin{array}{l}331 \\
520 \\
553 \\
660 \\
492 \\
493 \\
457 \\
437 \\
453 \\
547 \\
569 \\
680 \\
492 \\
504 \\
471 \\
376 \\
575\end{array}$ & $\begin{array}{r}647 \\
828 \\
822 \\
1,046 \\
994 \\
956 \\
782 \\
739 \\
772 \\
846 \\
1,008 \\
1,006 \\
879 \\
991 \\
1,075 \\
975 \\
1,197\end{array}$ & $\begin{array}{r}738 \\
957 \\
1,093 \\
1,269 \\
1,193 \\
1,126 \\
983 \\
936 \\
1,118 \\
1,247 \\
1,356 \\
1,486 \\
1,319 \\
1,448 \\
1,446 \\
1,454 \\
1,683\end{array}$ & $\begin{array}{r}68 \\
116 \\
105 \\
151 \\
151 \\
146 \\
113 \\
126 \\
134 \\
132 \\
152 \\
190 \\
158 \\
151 \\
176 \\
157 \\
165\end{array}$ & $\begin{array}{r}88 \\
117 \\
124 \\
169 \\
145 \\
171 \\
154 \\
136 \\
179 \\
182 \\
177 \\
199 \\
220 \\
203 \\
207 \\
204 \\
204\end{array}$ & $\begin{array}{l}1,043 \\
1,442 \\
1,418 \\
1,860 \\
1,572 \\
1,550 \\
1,328 \\
1,243 \\
1,348 \\
1,407 \\
1,739 \\
1,794 \\
1,474 \\
1,630 \\
1,676 \\
1,507 \\
1,881\end{array}$ & $\begin{array}{l}1,157 \\
1,594 \\
1,770 \\
2,098 \\
1,830 \\
1,790 \\
1,594 \\
1,509 \\
1,750 \\
1,976 \\
2,102 \\
2,365 \\
2,031 \\
2,155 \\
2,124 \\
2,034 \\
2,462\end{array}$ \\
\hline Total & 8,018 & 8,610 & 15,503 & 20,852 & 2,391 & 2,879 & 25,912 & 32,341 \\
\hline
\end{tabular}

$M$ - masculine

$F$ - feminine

The patients with erythroderma (Table 4) showed the following distribution: in the group of from 0 to 15 years old, there was a predominance of feminine patients (Goodman $G$ statistics $=3.790$; c.p. $=2.448$ ), and anongst those over 61 years of age, there was a predominance of masculine patients (Goodman $\mathrm{G}$ statistics = 2.571 ; c.p. $=2.448$ ). The highest number of patients was found to be in the group of from 16 to 60 years old.

Table 4 - Distribution of patients with erythroderma according to sex and age (Jan/62-Mar/85).

\begin{tabular}{lrcr}
\hline Age (years) & Masculine & Feminine & Total \\
\hline $0-15$ & 8 & 20 & 28 \\
$16-60$ & 120 & 57 & 177 \\
$61+$ & 34 & 8 & 42 \\
\hline Total & 162 & 85 & 247 \\
\hline
\end{tabular}

Amongst the masculine group (Table 5), erythroderma was more frequent in the group of from 60 to 69 years old (Goodman G statistics $=3.885$; c.p. $=3.751$ ), while amongst the female group it was more frequent in the 10 to 19 year age group.

The majority of the patients were born in $\mathbf{S}$. Paulo state $(44.6 \%)$, in spite of the fact that the patients' places of birth have not been recorded in about $40.0 \%$ of the cases (Table 6).
Table 5 - Distribution by decades of patients with erythroderma according to sex and age (Jan/62-Mar/85).

\begin{tabular}{lccc}
\hline Age (years) & Masculine & Feminine & Total \\
\hline 0.9 & 6 & 10 & 16 \\
$10-19$ & 4 & 17 & 21 \\
$20-29$ & 25 & 13 & 38 \\
30.39 & 25 & 16 & 41 \\
$40-49$ & 34 & 11 & 45 \\
50.59 & 31 & 9 & 40 \\
$60-69$ & 24 & 3 & 27 \\
$70+$ & 13 & 6 & 19 \\
\hline Total & 162 & 85 & 247 \\
\hline
\end{tabular}

Table 6 - Birth places of patients with erythroderma (Jan/62 - Mar/85).

\begin{tabular}{lcr}
\hline Place of birth & \multicolumn{2}{c}{ Patients } \\
\cline { 2 - 3 } & $n$ & $\%$ \\
\hline S. Paulo Clty & 55 & 22.3 \\
S. Paulo State & 55 & 22.3 \\
Brazil (other states) & 37 & 15.0 \\
Other countries & 2 & 0.8 \\
No information & 98 & 39.6 \\
\hline Total & & 100.0 \\
\hline
\end{tabular}

Applying the Goodman's test to Table 7 (Goodman's $\gamma^{2}=2.448$; c.p. $=12.592$ ), no significant difference was found among the ratio of various causes, by sex. 
Table 7 - Distributlon of patients with erythroderma according to clinical manifestation and sex sub-groups, by total numbers (n) and percentages (\%) (Jar/62 - Mar/85).

\begin{tabular}{|c|c|c|c|c|c|c|}
\hline \multirow{3}{*}{ Diagnosis } & \multicolumn{6}{|c|}{ Patients } \\
\hline & \multicolumn{3}{|c|}{$n$} & \multicolumn{3}{|c|}{$\%$} \\
\hline & $M$ & $F$ & $T$ & $M$ & $F$ & $\mathrm{~T}$ \\
\hline
\end{tabular}

Previous dermatoses

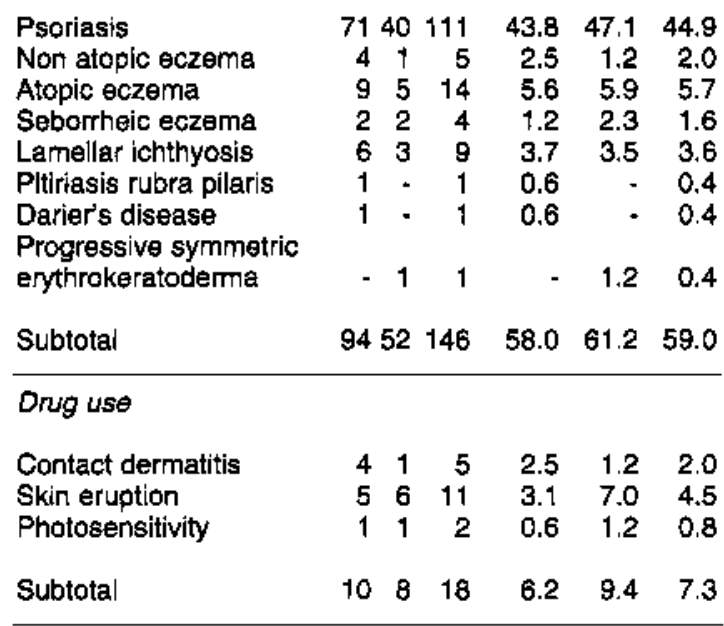

Asscciation with reticulosis

\begin{tabular}{lrrrrrr} 
Lymphoma & 5 & 2 & 7 & 3.1 & 2.4 & 2.9 \\
Sézary's syndrome & 3 & - & 3 & 1.9 & - & 1.2 \\
Subtotal & 8 & 2 & 10 & 5.0 & 2.4 & 4.1 \\
\hline
\end{tabular}

Miscellaneous

\begin{tabular}{lllllll} 
Nodular scabies & - & 1 & 1 & - & 1.2 & 0.4 \\
\hline Unknown causes & 50 & 22 & 72 & 30.8 & 25.8 & 29.2
\end{tabular}

\begin{tabular}{llllll}
\hline Unknown causes & 5022 & 72 & 30.8 & 25.8 & 29.2
\end{tabular}

\begin{tabular}{llll}
\hline Total & 16285247 & 100.0100 .0100 .0
\end{tabular}

$\mathrm{M}$ - masculine

$\mathrm{F}$ - feminine

A group of men between the 3rd and 6th decades, inclusive, of life, and of women between
1 st and 5th decades, inclusive, with psoriasis, was identified. Cutaneous eruption caused by the use of drugs was more frequent between the 2 nd and 5 th decades in both sexes (Table 8 ).

\section{Comments}

In the literature, there are few notes analyzing erythroderma under its multiple aspects (Abrahams et $\mathrm{al}^{1}$, Adam², Gatti et al ${ }^{6}$, Gentele et $\mathrm{al}^{7}$, Hasan \& Jansen', Montgomery', Nicolis \& Helwig ${ }^{14}$, Nigam et $\mathbf{l}^{15}$ and Rabello et al)..$^{16}$

Initially, the group of patients with erythroderma and the group of patients with other dermatosis were compared, in an attempt to find a sampling bias that might have resulted in a higher number of masculine patients in the group with erythroderma.

As no difference by sex was found when the population without erythroderma was studied (Table 1 and 3), it was concluded that the predominance of masculines in the group with erythroderma was not due to any sampling bias. This result is in agreement with those of other authors, ranging from 2: 1 (Adam $^{2}$ ) to 11: 1 (Nicolis \& Helwig). ${ }^{14}$

In more than $59.0 \%$ of the total cases there had been a prior manifestation of some dermatosis, of these cases, $44.9 \%$ had had psoriasis, $4.0 \%$ reticulosis/leukemia, and about $30.0 \%$ unknown causes (Table 7), with no difference among the ratio of the vaious causes according to sex. Therefore, in this population, the underlying disease was not responsible for the difference observed between the sexes in the group of patients with erythroderma (2 masculine: 1 feminine).

The literature shows that there is a predominance of some dermatosis as a prior manifestation in the group of patients with erythroderma (Abrahams et al'; Adam ${ }^{2}$; Gatti et $\mathrm{al}^{6}$, Gentele et $\mathrm{al}^{7}$ and Hasan \& Jansen). ${ }^{9}$ In literature, psoriasis is the

Table 8 - Distribution of patients with erythroderma, according to age, sex and diagnosis at the last visit (Jan62-Mar/85).

\begin{tabular}{|c|c|c|c|c|c|c|c|c|c|c|c|c|c|c|c|c|c|c|c|}
\hline \multirow[b]{2}{*}{ Diagnosis } & ge (years) & \multicolumn{2}{|c|}{0.9} & \multicolumn{2}{|c|}{$10-49$} & \multicolumn{2}{|c|}{$20-29$} & \multicolumn{2}{|c|}{$30-39$} & \multicolumn{2}{|c|}{$40-49$} & \multicolumn{2}{|c|}{$50-59$} & \multicolumn{2}{|c|}{$60-69$} & \multicolumn{2}{|c|}{$70+$} & \multicolumn{2}{|c|}{ Total } \\
\hline & Sex & $M$ & $F$ & $M$ & $F$ & $M$ & $\mathbf{F}$ & $M$ & $F$ & $M$ & $F$ & $M$ & $F$ & $M$ & $F$ & $M$ & $F$ & $\mathrm{M}$ & $F$ \\
\hline \multirow{5}{*}{\multicolumn{2}{|c|}{$\begin{array}{l}\text { Psoriasis } \\
\text { Drug use eruption } \\
\text { Atopic dermatitis } \\
\text { Unknown causes } \\
\text { Others }\end{array}$}} & 1 & 5 & 1 & 11 & 1 & 7 & 1 & 4 & 16 & 5 & 0 & & 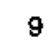 & & 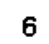 & & 71 & 40 \\
\hline & & - & - & 1 & 1 & 1 & 1 & - & 3 & 1 & 1 & 2 & - & 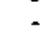 & 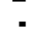 & . & 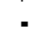 & 5 & 6 \\
\hline & & - & - & - & 2 & 2 & - & 7 & - & - & 2 & - & 1 & - & - & - & - & 9 & 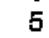 \\
\hline & & 2 & - & 2 & 1 & 6 & 4 & - & 7 & 12 & 4 & 14 & - & 9 & 1 & 5 & 5 & 50 & 22 \\
\hline & & 3 & 3 & 1 & 2 & 2 & 2 & 3 & 2 & 6 & - & 5 & 2 & 5 & - & 2 & 1 & 27 & 12 \\
\hline \multicolumn{2}{|l|}{ Total } & 6 & 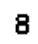 & 5 & 17 & 25 & 14 & 25 & 16 & 35 & 18 & 30 & $v$ & 23 & 3 & 13 & 8 & 162 & 85 \\
\hline
\end{tabular}

$M-$ masculine

$\mathrm{F}$ - feminine 
most frequent dermatosis $(25.0$ to $60.0 \%)$, although no sensu strictu comparisons between the literature and our data could be made, since the diagnosis and criteria of inclusion varied so much. This is perhaps the cause of the predominance of cases of drug reaction in Nicolis \& Helwig's study ${ }^{14}$ and the great number of cases of reticulosis in Montgomery's study ${ }^{\prime 2}$.

The frequency of unknown causes with erythroderma varied from $8.0 \%$ (Montgomery) ${ }^{14}$ to $55.0 \%$ (Rabello), ${ }^{16}$ against $29.0 \%$ in this present study. It is interesting to note that Montgomery ${ }^{12}$ had undertaken more skin biopsies than any other author.

It is not easy to compare the data of cases related to the use of drug in the present study with those recorded in the literature because of the great number of drugs involved and the difference in the criteria of inclusion. There are many available drugs and they vary from one country to another and from one time to another, as observed by Nigam et a ${ }^{15}$. Moreover, some authors consider any drug used before the appearance of erythroderma as the causal agent, whereas others do not do so when a primary dermatosis is present.

Only $19.4 \%$ of the cases gave any information regarding to the use of drugs prior to the development of erythroderna, and even in these cases, no information about the means of administration or dosage was available. The history of the use of corticosteroid just before the manifestation of erythroderma raised the question as to a possible cause in the inadequate treatment of a previous dermatosis.

All six patients involved with agrotoxic products were men (Tables 9 and 10) of from 30 to 60 years old and came from the countryside. In spite of the small sample, it was asked wether environmental antigens might not be causally related to
Table 9 - Places where patients with erythroderma came from with history of drug use before the clinical manifestation of erythroderma (Jan/62-Mar/85).

\begin{tabular}{lcccr}
\hline & \multicolumn{4}{c}{ Place of origin } \\
\cline { 2 - 6 } Drug group & $\begin{array}{c}\text { S. Paulo } \\
\text { City }\end{array}$ & $\begin{array}{c}\text { S. Paulo } \\
\text { State }\end{array}$ & Other Total \\
\hline Antibiotics and & & & & \\
chemotherapic & 4 & 2 & 2 & 8 \\
$\begin{array}{l}\text { agents } \\
\text { Corticosteroids }\end{array}$ & 6 & 7 & 2 & 15 \\
Anti-histamines & 4 & 1 & 2 & 7 \\
Agrotoxic products & - & 3 & 3 & 6 \\
Others & 4 & 7 & 1 & 12 \\
\hline Total & 18 & 20 & 10 & 48 \\
\hline
\end{tabular}

Table 10 - Distribution of patients with erythroderma with a history of drug use according to sex and drug type (Jan/62-Mar/85).

\begin{tabular}{lccr}
\hline Drug group & Masçuline & Feminine & Total \\
\hline Antiblotics and & & & \\
chemotherapeutic agents & 4 & 4 & 8 \\
Corticosteroids & 10 & 5 & 15 \\
Anti-histamines & 2 & 5 & 7 \\
Toxic products & 6 & - & 6 \\
Others & 7 & 5 & 12 \\
\hline Total & 29 & 19 & 48 \\
\hline
\end{tabular}

erythroderma, and whether the predominance of masculine patients amongst the group with erythroderma could be due to their work-related exposure to the environmental antigens.

One hundred seventy three skin biopsies ( 1 to 3 biopsies/patient) were performed. Ninety-eight biopsies (about $60.0 \%$ ) were either diagnostic or suggestive of the underlying diseases, and 75 biopsies (about 40.0\%) were non-diagnostic (Table 11).

Table 11 - Comparlson between clinical diagnosis and histopathologic results in patients with erythroderma (Jan/62-Mar/85).

Histopathologic Results

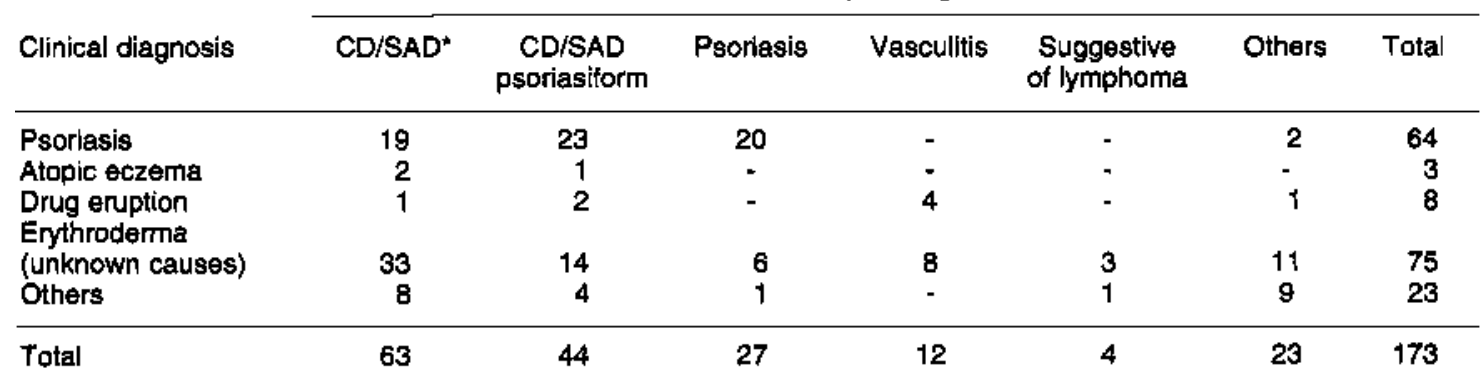

* $C D=$ chronic dermatitis

$S A D=$ subacute dermatltis 
The data from this research corroborate the previous findings of Montgomery's 1933 study $^{12}$ that skin biopsies, when performed in sufficient numbers, and under appropriate conditions, are still the best mean of diagnosis and follow-up for patients with erythroderma. Skin biopsy is specially useful in the diagnosis or exclusion of an early reticulosis, since the latter process shows earlier changes in the skin than in other organs (Montgomery). ${ }^{12}$

Another biopsy is recommended when a patient shows a poor therapeutic response and when the

\section{References}

1. ABRAHAMS, I.; MC CARTHY, J. T.; SANDERS, S. $\mathrm{L}$. One hundred and one cases of exfoliative dermatitis. Arch.Dermatol., 87: 96-101,1963.

2. ADAM, J. E. Exfoliative dermatitis. Can.Med.Ass.J., 99: 661-9, 1968.

3. COSTA-NETO,P. L. O. Estatística. Sảo Paulo. Ed. Edgar Blucher Ltda., 1977.

4. FITZPATRICK, T. B.; EISEN', A. Z; WOLFF, K. FREEDBERG, M. I.; ALSTEN, K. F. Dermatology in general medicine, 2nd.ed. New York. Mc Graw-Hill Inc., 1979.

5. FORATTINI, O. P. Epidemiologia geral. São Paulo, Artes Médicas, 1980.

6. GATTI, C. F.; VILLAMIL, S; GARCIA, N. Eritrodermias: experiencia sobre 30 casos. Arch.Angent.Derm.,31: 69-74, 1981.

7. GENTELE, H.; LODIN, A; SKOG, E. Dermatitis exfoliativa: cases admitted in the decade 1948-1957 to the Dermatological Clinic, Karolinska Sjukhuset, Stockholm, Sweden. Acta Dermato-Venereol., 38: 296-302, 1958.

8. GOODMAN, L. A. Simultaneous confidence intervals for contrasts among multinomial populations. Statistics, 35: 716-25, 1964 .

9. HASAN, T. \& JANSEN, C. T. Erythroderma: a follow-up of fifty cases. J.Am.Acad.Dermatol, 8 : $836-40,1983$ histologic feature is not cleared-up. as may happen the differential diagnosis of Sézary's erythroderma versus pre-Sézary's erythroderma, mycosis fungoides versus persistent reaction to insect bites, and nodular scabies versus mycosis fungoides or Hodgkin's lymphoma (Montgomery). ${ }^{12}$

In striving for an ideal biopsy, the following advice from Montgomery ${ }^{2}$ should always be kept up in mind: whenever possible, biopsies should be done on an untreated active area, away from the abdomen or seborrheic areas.
10. HELM, F. Cancer dermatology. Philadelphia, Lea and Ferbiger, 1979 .

11. LESER, W.; BARBOSA, V.; BARLZZI, R.; RIBEIRO, M. B.; FRANCO, L. J. Elementos de epidemiologia geral. Sào Paulo, Livraria Atheneu, 1985

12. MONTGOMERY, $H$. Exfoliative dermatosis and malignant erythroderma: the value and limitations of hystopathologic studies. $A r c b$. Dermatol.Sypb.,27: 253-73, 1933.

13. NEBENZAHL, S. R; ROSA, R. L. A.; NOBRE, A. A. Eritrodermia: atualização, J.Bras.Med,46: 71-93,1984.

14. NICOLIS, G. D. \& HELWIG, E. B. Exfoliative Dermatitis: a clinicopathologic study of 135 cases. Arcb.Dermatol, 108: 788-97, 1973

15. NIGAM, P.; GOYAL, B. M.; MISHRA, D. Ni; SAMUEI, K. G. Exfoliative dermatitis; study of systemic manifestations. Indian J. Dermatol. Venereol, 43: 145-8, 1977

16. RABELLO, F. E. AZULAY, R. D.; ANTLNES, A. G.; VILLELA-PEDRASJ.A. Eritrodermias exfoliativas. An. Bras. Dermatol. Siflol, 28(3): 153-74, 1953.

17. ROOK,A; WLIKINSON,D.S.; EBLING,F,J.G. Textbook of dermatology. 3rd. ed, London. Blackwell Scientific Publ, 1979.

18. SAMPAIO, S. A. P.; CASTRO, R. M.;RIVITTI, E. A. Dermatologia básica. Sào Paulo, 2a. ed. Artes Médicas, 1978 .

\section{Resumo}

Foi analisado o perfil de 247 doentes com eritrodermia em um período de 23 anos, de janeiro de 1962 a março de 1985 , com o período de seguimento variando de 1 a 26 anos. Os doentes se apresentavam com eritema universal, descamaçāo $\theta$ prurido com mais de 2 meses de duração e a idade variava de 16 a 60 anos. A psoríase foi a doença associada mais frequente, com uma proporcāo estimada de $44,9 \%$, as reaçōes cutáneas ao uso de drogas contribuiram com 7,3\% do total de casos e a associaçäo com reticuloses mostrou uma proporçăo de 4,1\%. A eritrodermia permaneceu como de causa desconhecida em $29,2 \%$ dos casos. Não foram observadas diferencas entre os sexos no que diz respeito à doença associada. Um ou mals resultados anatomo patológicos das biopsias de pele, em conjunto com o quadro clínico, fol diagnóstico ou sugestivo do diagnóstico da doença associada em $63,6 \%$ dos casos. Recomendam-se biópsias de pele seriadas como o melhor método para a elucidaçáo diagnóstica da eritrodemia. Ao nivel de significancla $P=0,05$, fol encontrada uma proporcäo homem/mulher de $2: 1$. Especula-se se o agente causal da eritrodermia estaria relacionado à exposiçâo diferenciada entre os sexos a antigenos do meio ambiente.

Dermatite esfoliativa, epidemiologia. Incidência. 